\title{
Evaluation of Toxicity and Gene Expression Changes Triggered by Quantum Dots
}

\author{
Pooja Dua, ${ }^{\dagger,+, a}$ Sohee Jeong, ${ }^{\S, a}$ Shi-Eun Lee, ${ }^{\dagger}$ Sun Woo Hong, ${ }^{\dagger}$ Soyoun Kim, ${ }^{\dagger, *}$ and Dong-ki Lee ${ }^{\dagger, *}$ \\ ${ }^{\dagger}$ Global Research Laboratory for RNAi Medicine, Department of Chemistry and BK21 School of Chemical Materials Science, \\ Sungkyunkwan University, Suwon 440-746 Korea. *E-mail: dklee@skku.edu \\ ${ }^{\star}$ Department of Biomedical Engineering, Dongguk University, Seoul 100-715 Korea. *E-mail: skim@dongguk.edu \\ ${ }^{\S}$ Nanomechanical Systems Research Division, Korea Institute of Machinery and Materials, Daejeon 305-343 Korea \\ Received February 10, 2010, Accepted April 13, 2010
}

\begin{abstract}
Quantum dots (QDs) are extensively employed for biomedical research as a fluorescence reporter and their use for various labeling applications will continue to increase as they are preferred over conventional labeling methods for various reasons. However, concerns have been raised over the toxicity of these particles in the biological system. Till date no thorough investigation has been carried out to identify the molecular signatures of QD mediated toxicity. In this study we evaluated the toxicity of $\mathrm{CdSe}, \mathrm{Cd}_{1-\mathrm{x}} \mathrm{Zn}_{\mathrm{x}} \mathrm{S} / \mathrm{ZnS}$ and $\mathrm{CdSe} / \mathrm{ZnS}$ quantum dots having different spectral properties (red, blue, green) using human embryonic kidney fibroblast cells (HEK293). Cell viability assay for both short and long duration exposure show concentration material dependent toxicity, in the order of $\mathrm{CdSe}>\mathrm{Cd}{ }_{1-\mathrm{x}} \mathrm{Zn}_{\mathrm{x}} \mathrm{S} /$ $\mathrm{ZnS}>\mathrm{CdSe} / \mathrm{ZnS}$. Genome wide changes in the expression of genes upon QD exposure was also analyzed by wholegenome microarray. All the three QDs show increase in the expression of genes related to apoptosis, inflammation and response towards stress and wounding. Further comparison of coated versus uncoated CdSe QD-mediated cell death and molecular changes suggests that ZnS coating could reduce QD mediated cytotoxicity to some extent only.
\end{abstract}

Key Words: Quantum dot, CdSe/ZnS, $\mathrm{Cd}_{1-\mathrm{x}} \mathrm{Zn}_{\mathrm{x}} \mathrm{S} / \mathrm{ZnS}, \mathrm{HEK} 293$ cells, Cytotoxicity

\section{Introduction}

Quantum dots (QDs) are nanocrystals (2 - $10 \mathrm{~nm})$ with sizedependent electrical and optical properties. They are zero dimensional particles composed of semiconductor material core such as cadmium selenide, cadmium sulphide, lead selenide, or indium arsenide (CdSe, CdS PbSe, or InAs) surrounded by shell of a high band-gap semiconductor, such as $\mathrm{ZnS}$ that increases the quantum yield upto $80 \%$. The core-shell architecture confines the excitation and emission to the core which enhances the photoluminescence quantum yield of the core emission and protects the core from photobleaching. ${ }^{2}$ Moreover, due to the quantum confinement effect, quantum dot of same material but with different sizes emit light of different wavelength imparting different flourescence spectrum. The larger the crystal size is, lesser is the energy emitted (towards red). Conversely, smaller sized dots produce higher energy (towards blue). Color-saturated deep blue light-emitting diodes, Cd1-xZnxS@ZnS with narrow band width and high quantum efficiency owing to the improved interface between cores and thick $\mathrm{ZnS}$ protecting shells have also been made. ${ }^{3}$ These QD have found extensive applications in electrical, optical and electro-optical devices. Quantum dots have been estimated to be up to 20 times brighter and 100 times more stable than traditional organic fluorescent reporters. ${ }^{1}$ Owing to their unique nature they are considered as attractive tool in the field of bioimaging and diagnosis. They are highly conducive for untrasensitive cellular imaging and cell-tracking for long durations. ${ }^{4,5,6-8}$ Besides, they have labeling applications in a wide range of assays such as immunoassays, optical encoding for multiplexed analyses, fluorescence resonance energy transfer (FRET), biosensors. ${ }^{9,10,11}$ They have also

${ }^{\mathrm{a}}$ These authors contributed equally. been used as photosensitizers for photodynamic therapy. ${ }^{12}$

Having heavy metal core, QDs are believed to have potential toxicity issues. Cadmium ions have been shown to bind to thiol groups present on mitochondrial proteins causing stress and cell death. ${ }^{13,14}$ Studies have shown that oxidation of CdSe QDs surface before solubilization or due to UV induced photolysis leads to oxidation of selenium, releasing free cadmium. ${ }^{15}$ Coatings used to increase photoluminescence, to some extent reduces toxicity of the core material. However, upon prolonged exposure to UV, even the sulfur of the $\mathrm{ZnS}$ shell gets oxidized disrupting the outer insulating layer and exposing the CdSe core to the environment. Additional capping materials, especially mercaptopropionic acid (MPA), also cause toxicity. ${ }^{16}$ In vitro studies on QDs mediated toxicity, in neuroblastoma cells, suggests that QDs mainly impart toxicity by disrupting mitochondrial pathways. CdSe-core QD induced JNK activation and mitochondrial-dependent apoptotic processes while inhibiting Ras--ERK survival signaling. ZnS coating was found to reduce QD-core mediated toxicity. ${ }^{17}$ In an another study on neuroblastoma cells, CdTe QDs mediated toxicity was found to be via Fas upregulation and lipid peroxidation, ultimately resulting in mitochondrial functional impairment. ${ }^{18}$ Human monocytes exposed to $\mathrm{CdSe} / \mathrm{ZnS}$ QDs showed induced levels of intracellular ROS levels and inflammatory cytokines. ${ }^{19}$ Effect of surface modulation of CdSe QDs by PEG or surfactant has also been tested in Caco-2 small intestine epithelial model. Uncoated CdSe resulted in reduction in cell viability and cell detachment which was significantly restored upon PEG conjugation.

Changes occurring at molecular level upon exposure of QDs have not been explored very well. An 'omics' platform like microarray which provides unbiased and comprehensive data, gives a snapshot of overall molecular changes occurring in the cells which could get unnoticed otherwise. In a study by Zang 
et al., effect of PEG-silane QDs on human skin fibroblast cells HSF-42 were studied at both phenotypic and molecular level. Although some cell death and necrotic changes were observed by imaging, no significant changes in expression, in number or magnitude were seen with genome-wide microarray. ${ }^{20}$ To better understand the toxicity of QDs of different material composition and coating, we performed genome wide microarray analysis of human embryonic kidney fibroblast cells (HEK-293) exposed to red, green and deep blue QDs at concentrations that show very marginal changes in cell viability.

\section{Experimental Section}

Cell culture and QDs. Human embryonic kidney 293 (HEK 293) cells were grown in the Dulbecco's Modified Eagle Medium (Gibco BRL) containing 10\% Fetal Bovine Serum (Gibco $\mathrm{BRL})$ and $1 \%$ Penicillin and Streptomycin. CdSe, $\mathrm{Cd}_{1-\mathrm{x}} \mathrm{Zn}_{\mathrm{x}} \mathrm{S} /$ $\mathrm{ZnS}$ and $\mathrm{CdSe} / \mathrm{ZnS}$ quantum dots were synthesized using previously reported colloidal routes. ${ }^{21-23}$ And further modified to make them disperse in PBS buffer. ${ }^{24,25}$ Briefly, CdSe/ZnS coreshell quantum dots were prepared via step-wise process of CdSe or $\mathrm{Cd}_{1-\mathrm{x}} \mathrm{Zn}_{\mathrm{x}} \mathrm{S}$ core synthesis followed by epitaxial growth of $\mathrm{ZnS}$. Resulting quantum dots were washed extensively to remove any residual surfactants and further encapsulated with octylamine-modified polyacrylic acid. Polymer encapsulated quantum dots were dispersed in PBS. Photoluminescence maximum wavelength of each QDs were 455, 550, $625 \mathrm{~nm}$, respectively.

WST-1 cell viability assay. HEK293 cells were seeded in 96-well cell culture plate at a density of $6 \times 10^{3}$ cells per well and incubated overnight. The cells were incubated with $\mathrm{CdSe} /$ $\mathrm{ZnS}$ (red), $\mathrm{Cd}_{1-\mathrm{x}} \mathrm{Zn}_{\mathrm{x}} \mathrm{S} / \mathrm{ZnS}$ (deep blue) and CdSe (green) at various concentrations in complete DMEM for 4 and $24 \mathrm{~h}$. For each concentration 6 well replicates were taken. Following incubation, $10 \mu \mathrm{L}$ of premix WST-1 reagent (TaKaRa) was added in each well and were further incubated for $2 \mathrm{~h}$. The color development was measured on an ELISA plate reader at $450 \mathrm{~nm}$. All absorbance values were corrected against blank which contained complete media alone. Percent cell viability was calculated considering untreated control as 100\% viable. Concentration that results in $50 \%$ cell death $\left(\mathrm{IC}_{50}\right)$ was calculated using Sigma plot10.0.

DNA microarray. Cells were grown to $60 \%$ cell density and treated with $\mathrm{CdSe} / \mathrm{ZnS}$ (red), $\mathrm{Cd}_{1-\mathrm{x}} \mathrm{Zn}_{\mathrm{x}} \mathrm{S} / \mathrm{ZnS}$ (deep blue), $\mathrm{CdSe}$ (green) in complete media for $4 \mathrm{~h}$. Total RNA was extracted using the TRI Reagent ${ }^{\circledR}$ kit (Ambion) according to manufacturer's instructions. $10 \mu \mathrm{g}$ of total RNA was used for each double-stranded cDNA (dscDNA) synthesis, employing a commercial kit (Invitrogen). Reactions were stopped with EDTA and the dscDNA treated with RNase A. Samples were ethanolprecipitated. $1 \mu \mathrm{g}$ of dscDNA was used for labeling by Klenow fragment (NEB) using Cy3-labeled random 9 mer (TriLink Biotechnologies) and labeled samples were precipitated using isopropanol. $4 \mu \mathrm{g}$ of Cy3-labeled DNA (containing sample tracking control and alignment oligo) was hybridized to Nimblegen $385 \mathrm{~K}$ 4-plex human microarray for $18 \mathrm{~h}$ at $42{ }^{\circ} \mathrm{C}$ using the Nimblegen Hybridization system (Nimblegen). Arrays were washed and array images were obtained using a GenePix 4000B scanner (Axon Instruments).
Microarray data analysis. Scanned images were imported into NimbleScan software (Nimblegen). Expression data was normalized through quantile normalization and Robust Multichip Average (RMA) algorithm. ${ }^{26}$ To visualize overall changes in gene expression MA plots were generated, where $\mathrm{X}$ axis represents the average of $\log _{2}$ expression of control and test samples and $\mathrm{Y}$ axis corresponds to ratio of $\log _{2}$ expression value of test to control. Fold changes in expression for 24,000 genes were calculated for each nanoparticle relative to untreated control. Transcripts with more than 2 fold changes in either direction were selected. Commonly regulated genes were clustered using Eisen Cluster Analysis and Visualization Software. ${ }^{27}$ The genes that were differentially expressed by the test materials were functionally categorized using a web based program, Database for Annotation, Visualization and Integrated Discovery (DAVID) ${ }^{28}$ Enrichment in gene ontology terms, for both upand down-regulated genes was seen at Fisher exact $\mathrm{p}<0.05$ and Count Threshold 2.

\section{Results and Discussion}

Synthesis and use of Quantum dots is continuously increasing due to their unique physicochemical properties and wide applications in biomedical sciences. Although there has been concerns about the toxicity they would impart due to the material they are composed of, yet, there is no sufficiently clear data in this regard. Moreover, the existing data derives contrasting conclusions which makes it even more difficult to classify QDs on toxicity scale. ${ }^{29,30}$ Therefore in the present study we have tried to understand the effect of exposure of QDs on human embryonic kidney fibroblast cells at both cellular and molecular level. We evaluated and compared the toxicity of QDs with different chemical composition and spectral properties. For this we used $\mathrm{CdSe} / \mathrm{ZnS}$ (red-625), $\mathrm{Cd}_{1-\mathrm{x}} \mathrm{Zn}_{\mathrm{x}} \mathrm{S} / \mathrm{ZnS}$ (deep blue-550), $\mathrm{CdSe}$ (green-455). Amongst these red and blue QDs were surface encapsulated with $\mathrm{ZnS}$, while green QD had a naked CdSe core.

To see the effect of QDs on HEK293 cell viability, cells were exposed to increasing concentrations of test materials for 4 and $24 \mathrm{~h}$ and cell viability was measured to account the toxicity at a cellular level. Untreated cells were used as control. In comparison to other existing assays used to measure metabolic activity of viable cells, WST-1 assay is the most sensitive and has least background interference; hence was used in our study. As shown in Fig. 1, QDs showed a concentration-dependent loss in cell viability. Reduction in cell viability was more prominent for $24 \mathrm{~h}$ incubation. Amongst QDs, green QD without $\mathrm{ZnS}$ shell coating was found to be most toxic with $\mathrm{IC}_{50}$ of $19.09 \mathrm{nM}$ and $8.35 \mathrm{nM}$ for 4 and $24 \mathrm{~h}$ respectively. Amongst the coated QDs, blue QD was found to be more toxic than red QD at both the time points. The cell viability data suggests that QD show material dependent toxicity. Even size could have been a factor governing the toxicity as small sized QDs show better cell permeabilization, as has been shown earlier with both CdSe and CdTe QDs. ${ }^{31,32}$ Moreover, the toxicity was seen to be increased without $\mathrm{ZnS}$ epitaxial coating, which is in agreement with the earlier published findings. ${ }^{17}$

To further study the QD mediated changes at molecular level 
(A)
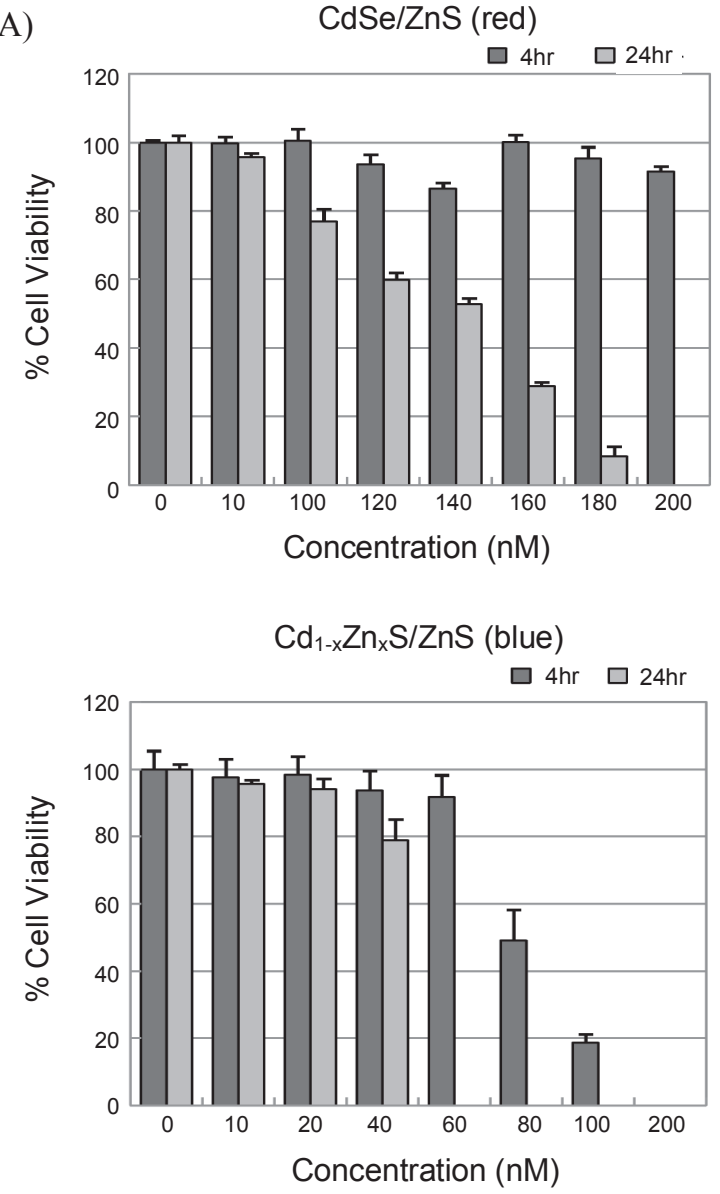

CdSe (green)

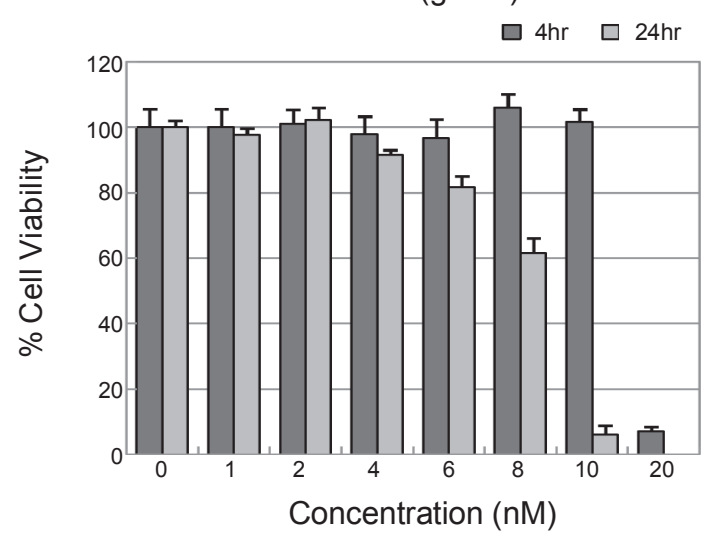

(B)

\begin{tabular}{ccc}
\hline QD & IC50 - 4hrs (nM) & IC50 - 24hrs (nM) \\
\hline $\mathrm{CdSe} / \mathrm{ZnS}$ (red) & ND & 135.98 \\
$\mathrm{Cd}_{1-\mathrm{x}} \mathrm{Zn} \mathrm{x}_{\mathrm{x}} \mathrm{S} / \mathrm{ZnS}$ (blue) & 79.81 & 42.34 \\
$\mathrm{CdSe}$ (green) & 19.09 & 8.35 \\
\hline
\end{tabular}

Figure 1. Effect of $\mathrm{CdSe} / \mathrm{ZnS}, \mathrm{Cd}_{1-\mathrm{x}} \mathrm{Zn}_{\mathrm{x}} \mathrm{S} / \mathrm{ZnS}$, CdSe on viability of HEK293 cells. Cell viability after 4 and $24 \mathrm{~h}$ exposure to the test compounds was determined by WST-1 assay (A). The data is represented as mean $\pm \mathrm{SE}$ of three independent experiments and is expressed as percent cell viability with respect to untreated control as $100 \%$ viable. The IC50 values of tested QDs as computed by Sigma plot 10.0 are given (B).
(A)

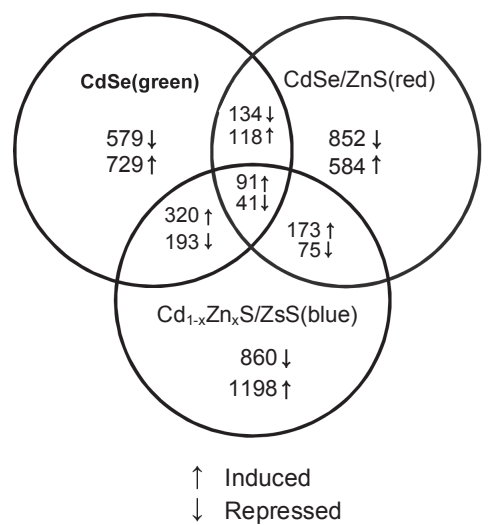

(B)

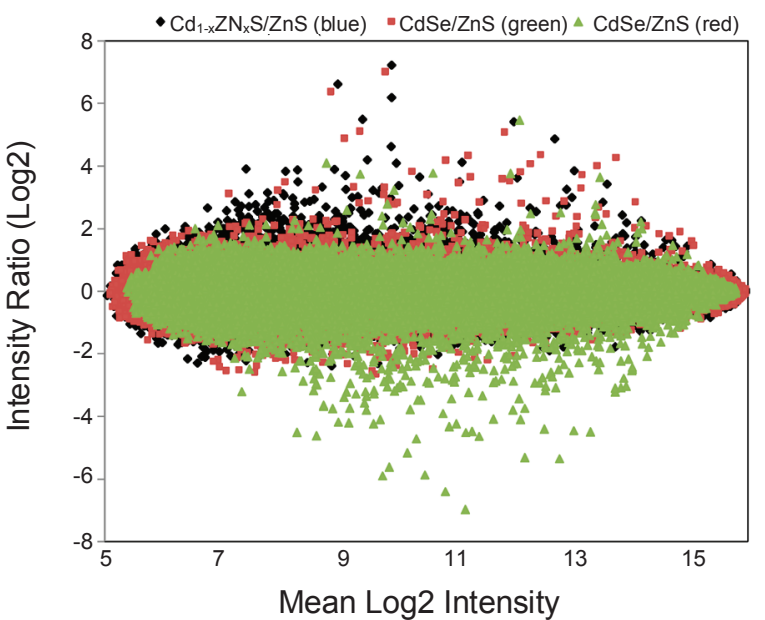

(C)

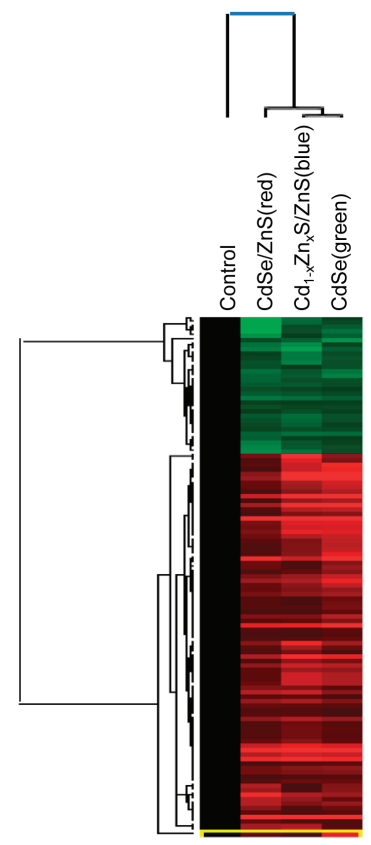

Figure 2. Venn diagrams illustrating genes induced or repressed by more than 2 fold upon nanoparticle exposure (A). MA Scatter plot showing overall distribution of gene expression upon nanoparticle exposure (B). The commonly regulated genes were clustered and tree view is given $(C)$. The red and green color represents $>2$ fold up and down-regulated genes respectively. 
(A)
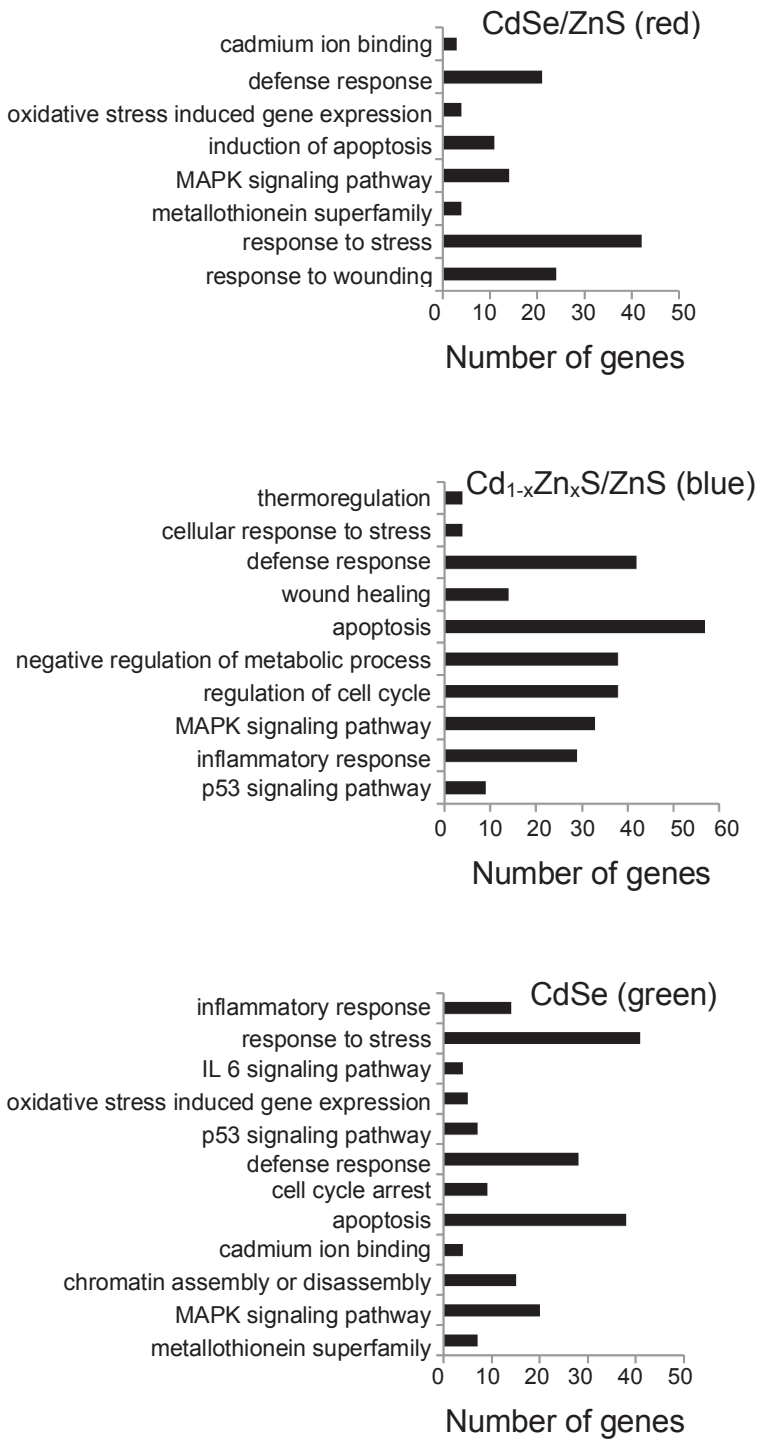

(B)
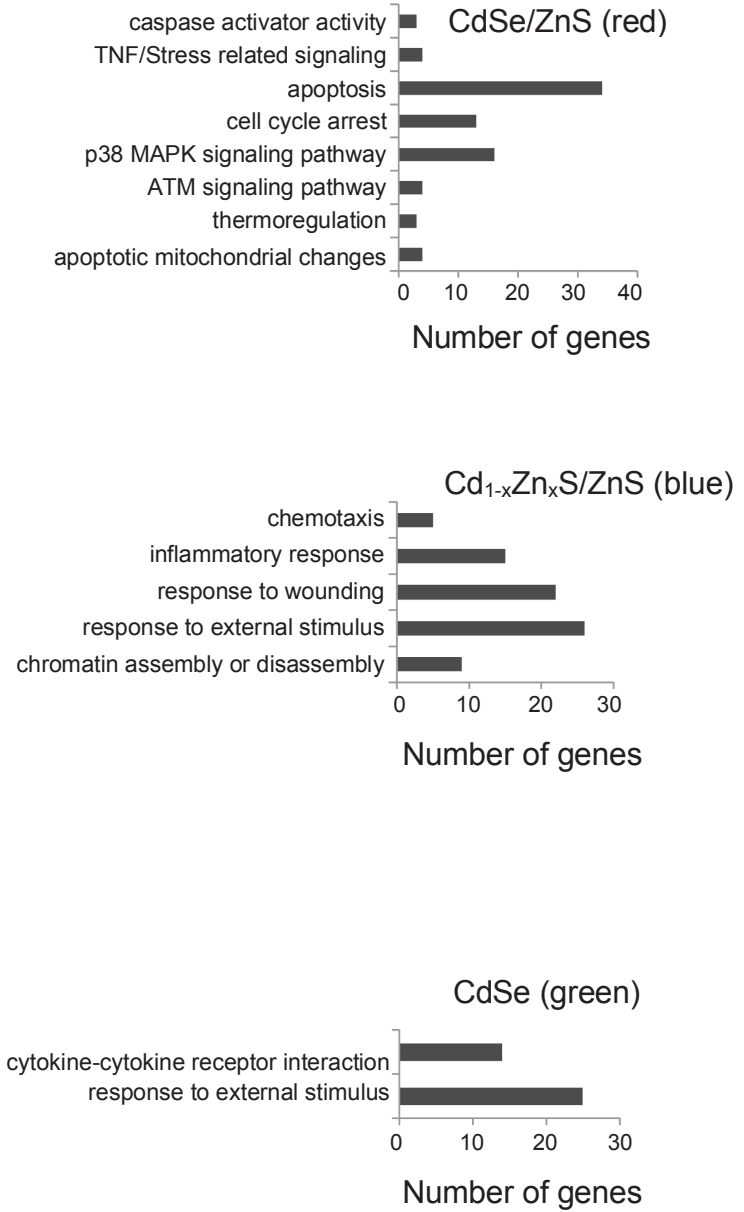

Figure 3. Categorization of more than 2 fold altered genes on the basis of their gene ontology, up-regulated (A) and down-regulated (B), using web based program, Database for Annotation, Visualization and Integrated Discovery (DAVID). Each bar represents the percent enrichment of the GO term against total altered genes as background.

and make a clear understanding of the toxicity, we performed DNA microarray analysis of HEK293 cells exposed to the test QDs. Cells were exposed to QDs for $4 \mathrm{~h}$, as even short duration of exposure was found to be sufficient to cause loss in cell viability. Functionalised QDs have been shown to be readily uptaken by rat pheochromocytoma cells and human macrophages within $1 \mathrm{~h} .{ }^{31,32}$ Moreover, to visualize early molecular events that would be triggered upon QD exposure, we concentrated upon short duration exposure and non-toxic concentrations. Molecular changes in toxicity were assessed at concentrations where no visible signs of toxicity were seen in an otherwise conventional cell death-based toxicity assay. Cells were incubated with $200 \mathrm{nM}, 60 \mathrm{nM}$ and $10 \mathrm{nM}$ of red, deep blue, and green QD respectively for $4 \mathrm{~h}$. Microarray was performed and the data was analyzed for changes in gene expression. As can be seen in Fig. 2, the number of genes up-regulated was more than the number of genes downregulated in blue and green QD, while in red QD larger number of genes showed highly reduced expression in comparison to relatively less number of induced genes. Altogether, 91 genes were commonly upregulated and 41 genes were downregulated, which is also shown in the tree view cluster analysis (Fig. 2C).

To make the data more meaningful and applicable, the gene expression changes were subjected to gene ontology analysis. As can be seen in Fig. 3A, response to wounding, cell stress, apoptosis and defense response functions were enriched in all the QDs studied. MAPK signaling was induced upon exposure to QD. MAPK pathway is the major cell survival and signaling pathway induced upon response towards environmental stimulus that leads to inflammation, apoptosis or proliferation and differentiation, and has been shown to induced by other nanoparticles as well. ${ }^{33}$ Expression of metallothionein superfamily (MTX 2a, MTX 1h, MTX 1g, MTX 1f) was induced upon red and green QD exposure. Metallothioneins are a family of 
cystein-rich metal binding proteins that are involved in metal detoxification and protection of cells against reactive oxygen species (ROS). These proteins are also upregulated upon exposure of $\mathrm{Cd}^{2+}$ ions. ${ }^{34}$ With both green and red emitting QDs cadmium ion mediated responses were enriched, suggesting that in case of CdSe core, both coated and non-coated, cadmium could leak out of the central core, which could be one of the main reasons of QD-associated toxic responses. This observation is in good agreement with earlier reported facts about QD toxicity. ${ }^{15,35}$ However, metallothionein gene expression was not seen to be induced with deep blue emitting quantum dots. Neither was any free $\mathrm{Cd}^{2+}$ mediated gene expression observed in this case, suggesting that $\mathrm{Cd}_{1-\mathrm{x}} \mathrm{Zn}_{\mathrm{x}} \mathrm{S} / \mathrm{ZnS}$, comparatively have more stable structure. The thick inorganic shell in these QDs due to extra zinc makes them highly resistant to environmental exposure. ${ }^{36}$ Also, oxidative stress mediated response-associated genes were seen to be induced by both red and green QDs, but not blue. In comparison to red and blue QDs, green QD showed much stronger enrichment in toxicity associated functions. IL6 signaling pathway (IL6R, vFOS, vJUN), cell cycle arrest and P53 signaling pathway (GADD45 (G,A,B), serpin1, PMA 1P1) was found to be strongly induced with these naked QDs. Amongst genes that were commonly up-regulated by all the three QDs, some showed association with inflammation and cell stress (FOSB, EGR1,TAK1, INHEB, RAB33A).

In comparison to the up-reguation in toxicity associated processes, very few toxicity associated functions were down-regulated (Fig. 3B). Down-regulated genes in red QD showed strong enrichment in antiapoptotic functions. Reduction in activation of Caspases and ATM damage sensing signaling pathway along with inhibition in $\mathrm{p} 38$ MAPK pathway was seen, which suggests that upon cellular DNA damage induced apoptosis and inflammation, cells respond and in turn try to inhibit the cell death by various mechanisms. Deep blue QD also showed reduction in expression of genes involved in inflammation and wounding.

\section{Conclusion}

HEK293 cells exposed to Cd based quantum dots with different spectral properties and material composition show toxic responses. The effect of QD exposure analysed by microarray analysis suggests that QDs induce expression of oxidative stress, apoptosis and inflammation associated genes which results in loss in cell viability. We should note that the polymer coating on the surface of QDs could potentially trigger the core materialindependent cytotoxicity. ${ }^{35}$ Nonetheless, the concentrationdependent cell viability assay suggests that at least for the three QDs tested in our experiment, QD mediated toxicity is mainly dependent on core material and $\mathrm{ZnS}$ coating partially reduces the toxicity of the metallic core. Overall, our results support the idea that the use of unmodified QDs for biomedical purposes should be followed with careful consideration.

Acknowledgments. This work was supported by the grant from Ministry of Environment as "The Eco-technopia 21 project" (091-081-073) and Global Research Laboratory grant 2008-00582 from National Research Foundation of Korea to
D.-k. L. P.D acknowledges the support from Sungkyunkwan University Post-doctoral Fellowship 2008. S. Jeong acknowledges the support from the Nano R\&D program through the Korea Science and Engineering Foundation funded by the Ministry of Education, Science and Technology (Grant 20090083219) and National Platform Technology Project of Ministry of Knowledge Economy.

\section{References}

1. Bruchez, M., Jr.; Moronne, M.; Gin, P.; Weiss, S.; Alivisatos, A. P. Science 1998, 281, 2013-2016.

2. Danek, M. J., K. F.; Murray, C. B.; Bawendi, M. G. Chem. Mater. 1996, 8, 173-180.

3. Ki Bae, W.; Kwak, J.; Lim, J.; Lee, D.; Ki Nam, M.; Char, K.; Lee, C.; Lee, S. Nanotechnology 2009, 20, 75202.

4. Tholouli, E.; Sweeney, E.; Barrow, E.; Clay, V.; Hoyland, J. A.; Byers, R. J. J. Pathol. 2008, 216, 275-285.

5. Cui, B.; Wu, C.; Chen, L.; Ramirez, A.; Bearer, E. L.; Li, W. P.; Mobley, W. C.; Chu, S. Proc. Natl. Acad. Sci. USA 2007, 104, 13666-13671.

6. Chan, W. C.; Nie, S. Science 1998, 281, 2016-2018.

7. Voura, E. B.; Jaiswal, J. K.; Mattoussi, H.; Simon, S. M. Nat. Med. 2004, 10, 993-998.

8. Walling, M. A.; Novak, J. A.; Shepard, J. R. Int. J. Mol. Sci. 2009, $10,441-491$

9. Medintz, I. L.; Konnert, J. H.; Clapp, A. R.; Stanish, I.; Twigg, M. E.; Mattoussi, H.; Mauro, J. M.; Deschamps, J. R. Proc. Natl. Acad. Sci. USA 2004, 101, 9612-9617.

10. Duong, H. D.; Rhee, J. I. Talanta 2007, 73, 899-905.

11. Kang, W. J.; Chae, J. R.; Cho, Y. L.; Lee, J. D.; Kim, S. Small 2009, 5, 2519-2522.

12. Yaghini E, S. A. Nanomedicine (Lond) 2009, 3, 353-363.

13. Rikans, L. E.; Yamano, T. J. Biochem. Mol. Toxicol. 2000, 14, 110-117.

14. Li, M.; Xia, T.; Jiang, C. S.; Li, L. J.; Fu, J. L.; Zhou, Z. C. Toxicology 2003, 194, 19-33.

15. Derfus, A. M. C.; W. C. W.; Bhatia, S. N. Nano Lett. 2004, 4, 2163-2169.

16. Hoshino A, F. K.; Oku, T.; Suga, M.; Sasaki, Y.; Ohta, T. Nano Lett. 2004, 4, 2163-2169.

17. Chan, W. H.; Shiao, N. H.; Lu, P. Z. Toxicol. Lett. 2006, 167, 191200.

18. Choi, A. O.; Cho, S. J.; Desbarats, J.; Lovric, J.; Maysinger, D. J. Nanobiotechnology 2007, 5, 1.

19. Lee, H. M.; Shin, D. M.; Song, H. M.; Yuk, J. M.; Lee, Z. W.; Lee, S. H.; Hwang, S. M.; Kim, J. M.; Lee, C. S.; Jo, E. K. Toxicol. Appl. Pharmacol. 2009, 238, 160-169.

20. Zhang, T.; Stilwell, J. L.; Gerion, D.; Ding, L.; Elboudwarej, O.; Cooke, P. A.; Gray, J. W.; Alivisatos, A. P.; Chen, F. F. Nano Lett. 2006, 6, 800-808.

21. Murray, C. B. N., D.; Bawendi, M. G. J. Am. Chem. Soc. 1993, 115, 8706-8715.

22. Bae, W. K. N., M. K.; Char, K.; Lee, S. Chem. Mater. 2008, 20 , 5017-5323.

23. Hines, M. A. G.-S., P. J. Phys. Chem. 1996, 100, 468-471.

24. Jeong, S.; Achermann, M.; Nanda, J.; Ivanov, S.; Klimov, V. I.; Hollingsworth, J. A. J. Am. Chem. Soc. 2005, 127, 10126-10127.

25. Wu, X.; Liu, H.; Liu, J.; Haley, K. N.; Treadway, J. A.; Larson, J. P.; Ge, N.; Peale, F.; Bruchez, M. P. Nat. Biotechnol. 2003, 21, 41-46.

26. Hong, S. W.; Hong, S. M.; Yoo, J. W.; Lee, Y. C.; Kim, S.; Lis, J. T.; Lee, D. K. Proc. Natl. Acad. Sci. USA 2009, 106, 14276-14280.

27. Eisen, M. B.; Spellman, P. T.; Brown, P. O.; Botstein, D. Proc. Natl. Acad. Sci. USA 1998, 95, 14863-14868.

28. Dennis, G., Jr.; Sherman, B. T.; Hosack, D. A.; Yang, J.; Gao, W.; Lane, H. C.; Lempicki, R. A. Genome. Biol. 2003, 4, 3. 
29. Geys, J.; Nemmar, A.; Verbeken, E.; Smolders, E.; Ratoi, M.; Hoylaerts, M. F.; Nemery, B.; Hoet, P. H. Environ. Health Perspect 2008, 116, 1607-1613.

30. Hauck, T. S.; Anderson, R. E.; Fischer, H. C.; Newbigging, S.; Chan, W. C. Small 2010, 6, 138-144.

31. Lovric, J.; Bazzi, H. S.; Cuie, Y.; Fortin, G. R.; Winnik, F. M.; Maysinger, D. J. Mol. Med. 2005, 83, 377-385.

32. Clift, M. J.; Rothen-Rutishauser, B.; Brown, D. M.; Duffin, R.; Donaldson, K.; Proudfoot, L.; Guy, K.; Stone, V. Toxicol. Appl. Pharmacol. 2008, 232, 418-427.
33. Park, E. J.; Yi, J.; Chung, K. H.; Ryu, D. Y.; Choi, J.; Park, K. Toxicol. Lett. 2008, 180, 222-229.

34. Klaassen, C. D.; Liu, J.; Diwan, B. A. Toxicol. Appl. Pharmacol. 2009, 238, 215-220.

35. Kirchner, C.; Liedl, T.; Kudera, S.; Pellegrino, T.; Munoz Javier, A.; Gaub, H. E.; Stolzle, S.; Fertig, N.; Parak, W. J. Nano Lett. 2005, 5, 331-338.

36. Chen, Y.; Vela, J.; Htoon, H.; Casson, J. L.; Werder, D. J.; Bussian, D. A.; Klimov, V. I.; Hollingsworth, J. A. J. Am. Chem. Soc. 2008, 130, 5026-5027. 